\title{
An Empirical Analysis of House Price Bubble: A Case Study of Beijing Housing Market
}

\author{
Ryan Dong Chen ${ }^{1}$, Christopher Gan ${ }^{1 *}$, Baiding $\mathrm{Hu}^{1} \&$ David A. Cohen ${ }^{2}$ \\ ${ }^{1}$ Department of Accounting, Economics and Finance, Faculty of Commerce, PO Box 84, \\ Lincoln University, Canterbury, New Zealand \\ ${ }^{2}$ Department Business Management, Law and Marketing, Faculty of Commerce, PO Box 84, \\ Lincoln University, Canterbury, New Zealand \\ *Corresponding author: Faculty of Commerce, Department of Accounting, Economics and \\ Finance, PO Box 84, Lincoln University, Canterbury, New Zealand
}

Tel: 64-3-325-2811Ｅ-mail: Christopher.Gan@Lincoln.ac.nz

Received: November 26, 2012 Accepted: January 24, 2013 Published: March 25, 2013

doi:10.5296/rae.v5i1.3433 URL: http://dx.doi.org/10.5296/rae.v5i1.3433

\begin{abstract}
Increases in house prices can lead to higher house price volatility, a significant determinant of default and the prepayment of housing loans (Miles, 2008). Many researchers believe that significant growth in house price has the potential to generate a house price bubble. The bursting of a house price bubble is likely to endanger the stability of the country's real economy.

China experienced substantial increases in house prices at the end of 1990s. In Beijing, house prices increased dramatically following the liberalization of China's housing market in 1998, and especially so after reforms in 2004. The significant growth of Beijing house prices could have generated a house price bubble, thus endangering the stability of the Beijing housing market and thereby the overall Chinese economy.

This paper investigates whether a bubble existed in the Beijing housing market from 1998 to 2010, using economic fundamental variables such as interest rates, inflation, and cost of supply. Results of the analysis revealed that the Beijing house price index was significantly larger than the equilibrium value, based on the relative economic fundamental variables (income, inflation, interest rate and construction cost) during 2004 to 2007. This result is similar to the findings of Hou (2009), where nearly 75 percent of the changes in Beijing house price were thought to be explained by the economic variables used in the models.
\end{abstract}

Keywords: house price bubble; interest rates; loans; China 


\section{Introduction}

The real estate market is described as inefficient and imperfect as compared with other financial markets. This is due to characteristics of the real estate market, which include such influences as fewer transactions, fewer participants, less liquidity and supply rigidities (Kang \& Gardner, 1989). These are believed to contribute to the deviation of given real estate market prices from the properties' fundamental values, which leads to the creation of a price bubble or boom in the real estate market (Xia \& Tan, 2007). The underlying market characteristics that can impact housing purchase prices are defined as an uncodified set of variables that contribute to determining an asset's price. These can include current values, dividends, and expectations about an asset's value in the future (Garber, 2000). The fundamental variables which often influence house prices are interest rates, income levels and inflation (Shiller, 2007).

The costs of bubbles are expensive, since they can expose a country to bubble-crashes and capital reversals (Caballero \& Krishnamurty, 2005). The bursting of a bubble in a housing market can generate a stronger negative impact on the economy compared with a stock market collapse. This is due to high transaction costs, illiquidity and heterogeneity of the housing characteristic (Helbling \& Terrones, 2003). The bursting of a house price bubble leads to a slow adjustment process, as house prices tend to revert to their equilibrium price. As a result, inefficient houses prices will prevail in the market for a longer period (Helbling \& Terrones, 2003).

As a real estate market plunges, banks and financial institutions lose billions as a result of overexpansion of the market (Kallberg et al., 2002). This loss soon spreads to other parts of the financial sector, resulting in different types of financial problems for institutions and individuals. These can include currency, banking, and stock market crises (Kallberg et al., 2002). For example, Reinhart and Rogoff (cited in Hayford and Malliaris, 2010) found that an asset price bubble is one of the main risks of systemic banking crises, due to credit over-expansion during the asset boom.

The current global financial crisis, where a wide variety of currencies are linked via the mechanisms of foreign exchange and investment, shows how a burst housing bubble can drag down the real economy globally. Since the middle 1990s, house prices in the U.S. have increased significantly. Prices continued to increase sharply even during the 2001 recession (McCarthy \& Peach, 2004). The factors that contributed to the emergence of the US house price bubbles have included low interest rates and poor lending standards (Krinsman, 2007). Low interest rates are believed to be the main contributing factor to triggering the expansion (boom) in the US real estate (Unterman, 2006), since this resulted in higher demand for houses as mortgage financing become cheaper (Crouhy et al., 2008). This rapid increase in house price perpetuated a large house price bubble which burst in 2007. The Federal National Mortgage Association ("Fannie Mae") and the Federal Home Loan Mortgage Corporation ("Freddie Mac"), both U.S. Government-sponsored businesses, were the first of the big mortgage companies to get into financial trouble. Following this, organisations offering mortgage-backed securities (MBS) and collateralized debt obligations (CDOs) experienced 
increasing losses (Kim \& Kim, 2009). These events started a bank crisis in the U.S.

The contagion of the subprime lending crisis spread from the US market to many other emerging markets such as those in the East Asian nations and Euro Zone countries such as Greece, Italy, Portugal and Ireland (Kim \& Kim, 2009). For example, Macquarie Bank in Australia declared losses of $25 \%$ for two bond issues, which were invested into senior loans in order to apply leverage. Similarly, the Taiwan Life Insurance Company also announced a loss on securities which were backed by subprime mortgages. Shin Kong Financial Holding Company, which owns the third largest life insurer in Taiwan, was also reported to have invested as much as US\$356 million in collateralized debt obligations in subprime mortgages in the US. The Bank of China also reported a significant loss of $\$ 9$ billion on investments in US subprime securities, which claimed the two hedge funds of the Bear Stearns Company (Bloomberg News, 2007).

The Chinese housing market also experienced dramatic increases in house prices at the end of 1990s. In Beijing, house prices increased dramatically following the liberalization of China's housing market in 1998, and especially so after reforms in 2004. The significant growth of Beijing house prices could have generated a house price bubble, endangering the Beijing housing market and thus the overall Chinese economy. Hou (2009) investigated house prices in Beijing and Shanghai, and reported that speculative behavior dramatically increased house prices in both cities, creating house price bubbles in Beijing (from 2005) and Shanghai (from 2003).

However, only a few studies have focussed on China's housing market bubble (see Shen et al., 2005; Hu et al., 2006; Leung \& Wang, 2007; Hou, 2009; Dreger \& Zhang, 2010). For example, Dreger and Zhang (2010) identified a housing bubble in China by using ratio analysis. Leung and Wang (2007) employed the DiPasquale and Wheaton model to test house price dynamics in China and confirmed the existence of a house price bubble. Similarly, Hou (2009) found empirical evidence to support the contention that house price bubbles exist in the Beijing and Shanghai housing markets. However, there does not appear to be a consensus on the existence of a house price bubble in China, with some researchers disputing the existence of one. For example, Hu et al. (2006) believed that the main engine of the increase in house prices was driven by economic fundamentals, such as the growth in personal income and variability of interest rates. Shen et al. (2005) tested the house price bubble hypothesis in Beijing and Shanghai by comparing market house price with the underlying economic fundamental based house price, finding a house bubble in Shanghai; however, for the Beijing housing market, the authors argued that the increase in house prices was due to fundamentals.

The literature on China's housing market mostly focuses on a few fundamental variables such as borrower's income and interest rates. For example, Hu et al. (2006) used these variables to model house price dynamics. Similarly, Hou (2009) used interest rate, income and rents to capture changes in house prices in China. However, there are few studies which test house prices by including house supply factors, such as construction costs, which impact prices. Construction costs directly affect the total housing supply costs of developers. To this point in time, the literature on the Chinese house market is focussed on the period before 2006. This 
study extends the data period to 2010 .

This paper investigates whether a bubble exists in the Beijing housing market from 1998 to 2010 and relies on economic fundamentals (e.g., interest rates, inflation, cost of supply). We adopt a model developed by Coleman et al. (2008) to estimate both the long term trend and short term dynamics of house prices in Beijing.

\section{Literature Review on Housing Bubbles}

Despite the complexity involved in measuring housing bubbles, many researchers have found empirical evidence to support the existence of them in housing markets globally. Case et al. (2005) suggest that the wealth effect, caused by changes in residential property prices, is bigger than other financial assets such as stock ownership. For example, Helbling and Terrones (2003) show that during the period 1970 to 2002, the declined output effects in US house prices caused by the bursting of housing bubbles were greater than in equity prices bubble bursts. Moreover, the slowing of an economy after a housing market collapse lasts about twice as long as that a after stock market crash (Malpezzi \& Wachter, 2005). Jannsen (2009) also found a long period of recession and an output loss for 15 OECD countries from 1970 to 2002 caused by a housing bubble crisis. It took four years for the respective GDPs to recover to their pre-crisis levels. This shows the severe impact on the economy caused by the bursting of a housing bubble (Jannsen, 2009).

Zhou and Sornette (2008), Goodman and Thibodeau (2008) and Abraham and Hendershott (1993, 1996) examined housing bubbles in the US. The Abraham and Hendershott studies revealed a $30 \%$ above-market premium in house prices in the Northeast US, and about a $15 \%$ to $20 \%$ premium in house prices on the West Coast. Their 1993 study integrated two proxies in the real estate market; one for the tendency of a bubble to burst, the other for the tendency of a bubble to swell. These proxies were found to work well to explain the large, cyclical swings in real estate prices on the West Coast of the US (Abraham \& Hendershott, 1993).

Capozza et al. (2004) also found variation in the movement of 62 house prices in US metropolitan areas. Using economic variables such as information cost, supply costs and expectations, the authors showed that the variation in these house prices was not caused by a common reaction to different economic shocks, but rather that house prices produce different reactions to different economic shocks. This demonstrates that variation in US house prices does not come from fundamental factors and that bubbles are the only rational explanation. Further evidence of bubbles in the US housing market was found in Las Vegas from June 1983 to March 2005. Zhou and Sornette (2008) analysed 27 Las Vegas house prices using 27 different zip (postal) codes. Defining real estate bubbles as the acceleration of prices faster than an exponential increase, the authors (2008) documented the existence of bubbles in Las Vegas house prices between 2003 and mid 2004, ending in 2005.

Similarly, house price bubbles have been reported in Europe. Using a cointegration and Markov-regime switching model, Garino and Sarno (2004) tested UK house prices with fundamental factors such as real personal disposable income per capita, treasury bill interest 
rates, mortgage rates and consumption expenditure deflator (CED) over the period 1983:Q1 to 2002:Q4. Zhou and Sornette (2003) developed an empirical model that utilised price growth and price oscillation to study the existence of bubbles in the UK residential market from December 1992 to April 2003. In both studies (Zhou \& Sornette, 2003: Garino \& Sarno, 2004), speculative bubbles were shown to exist in the UK housing market.

Clark et al. (2008) modeled the macro movement of UK national income, the London stock market and the UK house price index over the period 2001 to 2007. The authors used an ARIMA model to estimate the growth rate in house prices and found evidence of bubbles in UK house prices from 2001 to 2007. This is similar to the findings of Leamer (2007) and Taylor (2007), who examined the effect of high expansionary monetary policy in the housing market after the US September 11 attack.

Fraser, Hoesli and McAlevey (2008) found an overvaluation of house prices in New Zealand was an artifact of price dynamics, rather than an overreaction to economic fundamentals. The authors tested the difference between real house price and equilibrium price, and showed that real house price exceeded the real house value by 25\%. Hatzi \& Otto (2008) reported a mortgage speculation bubble in major cities such as Sydney. Only a quarter of the variation in the price-to-rent ratio could be explained by changes in economic fundamentals such as rent growth and real interest rates increase. This suggested that a speculative bubble existed in the housing market (also see Bourassa \& Hendershott, 1995; Bodman \& Crosby, 2004).

Studies have also documented substantial evidence of bubbles in Asian and East Asian countries such as Japan, Korea, Hong Kong, China and Thailand. Quigley (2001) argued that the over-booming and fluctuations of real estate markets in some Southeast and East Asian countries contributed to the 1997 Asian financial crisis. For example, Table 1 shows that Hong Kong and the Philippines housing markets were most severely affected by the Asian financial crisis. In Hong Kong, the house price index decreased by $61.34 \%$ and in Philippines by $56.20 \%$. Higher volatility in the Hong Kong housing market appears to have been caused by the availability of residential land and the monopolization of the market by a few real estate developers (Global Property Guide, 2009). For the Philippines, the decrease in the house price index was likely caused by high transaction costs in buying and selling property assets $(16.23 \%-23.75 \%)$ and the high volume of housing stock available in the market stemming from less demand by professional expatriates as the global economic recession took hold (Global Property Guide, 2007). 
Table 1: House Price Indexes Movement during and after the Asian Financial Crisis for Selected Asian countries

\begin{tabular}{lll}
\hline Country & During crisis period & After crisis period \\
\hline Hong Kong & $-61.34 \%(1997-2003)$ & $+60.72 \%(2003-2005)$ \\
Philippines & $-56.20 \%(1997-2000)$ & $+14.11 \%(2004-2005)$ \\
Indonesia & $-48.71 \%(1995-1999)$ & $+13.59 \%(1999-2005)$ \\
Singapore & $-45.57 \%(1996-1998)$ & $+20.31 \%(1997-2001)$ \\
South Korea & $-20.31 \%(1997-2001)$ & $+24.28 \%(2001-2003)$ \\
Thailand & $-19.54 \%(1997-1999)$ & $+29.34 \%(1999-2006$ \\
Malaysia & $-18.78 \%(1997-2006)$ & $+10.70 \%(1999-2005)$ \\
\hline
\end{tabular}

Source: Global Property Guide report (http://www.globalpropertyguide.com)

Calhoun (2003) examined house price indices (HPI) in Thailand from the pre-crisis period (1992) to the post-crisis period (2000). Using a hedonic property valuation model, Calhoun found significant regional differences in house price appreciation rates for both the pre-crisis and post-crisis periods. Thirty of 76 provinces in Thailand showed negative HPI appreciation rates from 1992 to 1997, while eight other provinces showed negative HPI appreciation rates of more than $30 \%$. In the post-crisis period (1997 to 2000), negative HPI appreciations were recorded in 69 of 76 provinces. Therefore, during the boom in the Thailand real estate market, many provinces seemed to experience negative growth in house prices (Calhoun, 2003). This conclusion was supported by Wong (2001), who also described the formation of bubbles in Thailand's housing market prior to the 1997 Asian financial crisis.

Kim and Suh (1993) found a particular form of bubble in the Japanese and Korean housing markets. The authors used an equilibrium price equation, which included the GDP stock price index and household consumption expenditure, and found evidence of both nominal and real bubbles in the Japanese market. They were unable to reject the null hypothesis of no bubbles in the Korean real housing prices. In another study, Kim (2004) used a Kalman Filter approach to estimate the size of housing price bubbles in Korea. The author showed that bubbles existed in the Korean housing market in the period 1992 to 2001 (except for 1998), with overvaluation in house prices ranging from $44 \%$ to $55 \%$.

Chan et al. (2001) used the signal extraction approach of Durlauf and Hall (1989) to detect the unobservable model noise and the misspecification error in three urban areas of the Hong Kong property market. Evidence of a bubble caused by misspecification error was found in Hong Kong Island, Kowloon and New Kowloon, with bubble explosions from 1990 to 1992 and from 1995 to 1997.

Wong (2008) found similar bubbles in the Hong Kong residential housing market. That study examined the movement in Hong Kong house prices, with the analysis including fundamental factors such as housing stock construction costs, population growth and interest rates, from 1992 to 1998. Xia and Tan (2007) used a Kalman Filter to test for an existence of bubbles from the 1980 s to the 1990 s in the Hong Kong property market. Using a combination of fundamental variables and speculative bubbles, Kalra et al., (2000) and Peng (2002) 
examined a Hong Kong property price model. Their study showed that half of the movements in Hong Kong property prices were explained by fundamental variables, with the other half due to the inflation of a bubble which tends to appear after the collapse of bubbles in some cases.

There is evidence that the strong growth in China's economy and rapid development of the real estate market have contributed to the increase of house prices in China. Qi and Li (2004) built a model to explain the increase in China's real estate prices by examining the relationship between real estate prices and bubbles. The results of their study show that three main factors have contributed to the increase of real estate prices in China and the formation of real estate bubbles. These include increased market demand for real estate assets, more opportunities in terms of credit from financial institutions and an oligopoly-type competitive market (Qi \& Li, 2004).

Shen et al. (2005) examined the Beijing and Shanghai housing markets using a Granger causality test and generalized impulse response analysis. The economic fundamentals utilised in the model included disposable income of urban households, GDP and the stock price indices for both cities. Results suggest that only the Shanghai housing market experienced a housing bubble in 2003. Shanghai housing prices deviated $22 \%$ from the market fundamental values and this deviation can be attributed to the bubble (Shen at al., 2005).

\section{Research Methods and Data}

There is no consensus as to which method is the best to estimate house price bubbles. Some researchers have used a ratio approach (see McCarthy \& Peach, 2004, 2005); some have relied on a user cost approach (asset-market approach) model (see Levin \& Wright, 1997), whilst still others have used the Vector error correction model (VECM) (see Case \& Shiller, 1989; Quigley, 1999; Sing et al., 2006). Thus, no single method seems to have universal approval for investigating the phenomenon.

Asset prices are determined by both demand and supply factors. Levin and Wright (1997) suggest the most common demand factors used to study house prices are income, inflation and interest rate. Many researchers also include construction cost as an important component of the supply side variables in studying house prices (see Meen, 1990; Malpezzi et al., 1998; Case \& Shiller, 2003). Meen (1990) successfully used construction cost, interest rate, income, inflation and after-tax interest rate in his empirical model to explain the mortgage rationing impact on U.K. housing market in a mortgage rationing period (1978 to 1980) as compared to a period when mortgage rationing was absent (1981 to 1987). Malpezzi et al. (1998) also identified construction cost as a major determinant of house prices in their study on house price index determination for 272 U.S. metropolitan areas. Similarly, Case and Shiller (2003) treated construction cost as an important element in studying house price bubbles in four states in the U.S.

When studying the house price in the short run, researchers tend to ignore the impact of supply factors on house price dynamics because of the assumption that house supply does not 


\section{Al Macrothink}

move in a short period. For example, using quarterly data, Black, Fraser \& Hoesli (2006) test the actual house prices relative to the house value in U.K., using only demand factors (income, inflation and interest rate). Some researchers use only inflation to capture the cost of supply (for example Coleman et al., 2008). However, the cost of supply in China's housing market changes over time; the inflation factor alone cannot capture the supply factors perfectly. Inflation is calculated by the changes in a standard basket of goods that cannot adequately estimate the supply costs (such as material and labor costs) dynamic. The present study employs both demand factors (income, inflation and interest rate) and supply factors to capture house price movement in Beijing.

In order to estimate both the long term trend and short term dynamics of house prices in Beijing, this study adopts Coleman et al.'s (2008) model based on the VECM. The model consists of the housing demand and housing supply equations, reproduced below.

$$
\begin{gathered}
Q_{D t}=\alpha_{t}+\beta_{1 t} P_{t}+\beta_{2 t} \operatorname{Inc}_{t}+\beta_{3 t} \operatorname{Intr}_{t}+\beta_{4 t} \operatorname{Inf}_{t}+\varepsilon_{D t} \\
Q_{S t}=a_{t}+b_{1 t} P_{t}+b_{2 t} C_{t}+\varepsilon S t
\end{gathered}
$$

Where:

$\mathrm{QDt}_{\text {Dt }}$ quantity of housing demand in period $\mathrm{t}$

QSt = quantity of housing supply in period $t$

$\alpha_{\mathrm{t}}$ and $\mathrm{at}_{\mathrm{t}}=$ intercepts

$\beta_{\mathrm{n}}$ and $\mathrm{b}_{\mathrm{n}}=$ coefficients

$\mathrm{P}_{\mathrm{t}}=$ housing prices

Inc $_{\mathrm{t}}=$ income

Intr ${ }_{\mathrm{t}}=$ short-term interest rate

Inf $=$ inflation

$\mathrm{C}_{\mathrm{t}}=$ cost for housing supply

$\mathcal{E D t}$ and $\boldsymbol{E S t}=$ error terms

The equilibrium condition is $\mathrm{QDt}_{\mathrm{Dt}}=\mathrm{QSt}_{\mathrm{St}}$. A house price equation can be defined as a reduced form equation with house price as the main endogenous variable, such as follows: 


$$
P_{t}=\alpha_{t}+\beta_{1 t} \operatorname{Inc}_{t}+\beta_{2 t} \operatorname{Intr}_{t}+\beta_{3 \mathrm{t}} \operatorname{Inf}_{t}+\beta_{4 t} C_{t}+\varepsilon t
$$

Where:

$$
\begin{aligned}
& \alpha_{\mathrm{t}}=\text { intercept } \\
& \boldsymbol{E}_{\mathrm{t}}=\text { error terms }
\end{aligned}
$$

Others variable are similarly defined as in equations 1 and 2

Equation 3 examines the long term trend and short-run dynamics of Beijing house prices. Yearly data from 1998 to 2010 was used to investigate the long-run trend and quarterly data from 2005:Q1 to 2010:Q4 to investigate short-run term dynamics of the house price in Beijing.

The Beijing house price index was utilised to measure the change in house prices, Beijing GDP as the income variable, the consumer price index (CPI) as an inflation variable and construction cost as the cost of supply. These four series data sets were obtained from the statistics department of Beijing government. The interest rate variable was obtained from the Bank of China website (http://www.boc.cn).

Previous studies of house prices suggest that GDP is a good proxy measure of income. For example, Green (1997) tested the relationship between GDP and house price, finding that it was a good predictor of residential investment. Similarly, Gauger and Synder (2003) examined the relationship between residential investment, money supply, interest rate and GDP using a VECM model in both pre-regulation (1959-1979) and post-regulation (1982-1999) sub-periods. The authors found a positive correlation between residential investment and GDP. The GDP in Beijing maintains a high growth rate of about 10 per cent, which is approximately the same as the trend for house price growth. GDP also positively correlates with house price (Pillay \& Rangel, 2005). Therefore, this study has used GDP as proxy for the income variable.

\section{Discussion of Empirical Results}

Results of long run regression analysis are presented in Table 2 below. These indicate that a substantial amount of the variation in the house price index (HPI), about $74.1 \%$, is explained by the model. The table also shows that the log of GDP growth is statistically significant and has a positive (20.0417) effect on the house price index for Beijing. This implies that if the speed of GDP growth increases by $1 \%$, house prices in Beijing will increase by $20 \%$. GDP growth (proxied by income) in the model captures the ability of consumers to purchase houses (also known as housing affordability). This result supports Gallin's (2003) study, where house price and income were linked in the long run via housing affordability; they tend to return to their long run equilibrium relationship, although in the short run such a relationship may drift due to speculation or other fundamentals such as easy credit. 
Linneman and Megbolugbe (1992) analyzed the U.S. housing market and found that affordability is one of the more important determinants of housing expenditures. The authors reported a positive relationship between household income and house price, which our findings confirm. Gallin (2006) investigated the long-run relationship between income and house prices in the U.S. housing market and concluded that there is a positive relationship between income and house prices at the national level.

Table 2: Estimated Results of the Long Run Model (Equation 3 with annual data)

\begin{tabular}{lllll}
\hline Dependent Variable: & HPI & & & \\
R-squared & 0.835461 & & & \\
Adjusted R-squared & 0.741439 & & & \\
S.E. of regression & 2.393222 & & & \\
Sum squared residual & 40.09258 & & & \\
Log likelihood & -24.26497 & & & \\
F-statistic & 8.885801 & & & \\
Probability (F-statistic) & 0.007091 & & & \\
Durbin-Watson statistic & 2.032336 & & & \\
\hline & Coefficient & Std. Error & t-Statistic & Prob. \\
\hline C & 41.98271 & 19.74111 & 2.126664 & 0.0710 \\
LOG(GDPGROWTH) & 20.04172 & 7.246538 & $2.765696^{* *}$ & 0.0279 \\
DLOG(CPI) & 44.16191 & 24.51272 & 1.801592 & 0.1146 \\
IR & 3.127505 & 1.373268 & $2.277418^{* *}$ & 0.0569 \\
SUPPLYCOST & 0.001269 & 0.000296 & $4.288998^{*}$ & 0.0036 \\
\hline
\end{tabular}

Note: $*$ and $* *$ indicate significance at $5 \%$ and $1 \%$, respectively

However, the CPI coefficient in the long run model shows the inflation variable does not significantly contribute. This result is consistent with Ji and Wang's (2011) study, where they compared the CPI and the PPI with HPI during the period from 2000 to 2010. Their analysis provided evidence that in the long run, CPI and HPI do not have a strict one-to-one correspondence. The authors pointed out that the CPI and HPI affect each other by creating "cost-driven upward pressure", but add that this channel is not stable; therefore, there does not appear to be a reliable, significant link between CPI and HPI in the long run.

Previous studies have documented a negative relationship between interest rate and house price (see for example Kau \& Keenan, 1980; Levin \& Pryce, 2007). This appears to be because most consumers cannot afford to pay cash for a house; thus, they will be forced to take out housing loans. Therefore, an increase in interest rate will increase borrowing cost, which in turn will decrease house demand.

However, some researchers have also reported an opposite conclusion. The Yun, Wang and Seabrook (2003) study showed a positive relationship between house price and interest rate in the Hong Kong housing market, known as the "Gibson paradox," as introduced by Keynes (1930). The same conclusion also appears in Ayuso, Blanco and Restoy's (2006) study of house prices in Spain and McQuinn and O'Reilly's study in Ireland (2006). In China's 
housing market, most researchers (for example Gao \& Wang, 2009; Wang \& Zhao, 2010) have found a positive relationship between house price and interest rate. Our research showed similar results in the long run model (the interest rate coefficient is 3.1275 , which is statistically significant at the $10 \%$ level). This is likely because the interest rate variable not only negatively impacts house price by increasing the borrowing cost for buyers, but also positively affects house price via the growth of borrowing cost for developers (Huang \& Wang, 2007).

Every year, thousands of people move to populous cities such as Beijing and Shanghai. The majority of these migrants are in the 20 to 40 years of age group. They include graduate students from universities and wealthy families looking for better educational opportunities for their children. Children cannot study and participate in the universities' entrance examinations in Beijing unless they are registered as residents of Beijing. Therefore, wealthy families buy houses in the city in order to gain registered residence. Such population growth in the cities leads to greater demand in the Beijing housing market.

Following the 1997 Asian financial crisis, the confidence of Chinese stock market investors was depressed. Because of limited alternatives, investors began to demand and speculate on mortgages. As a result, increasing interest rates would logically have had an impact on housing consumption in the long run. However, demand in the Beijing housing market did not change during our study period. Therefore, given a certain amount of house supply, developers appeared to be more sensitive to changes in the interest rate. When interest rate tracked up, the extent of the upward pressure from house developers would have been greater than the downward pressure from the house buyers.

The impact of supply cost on Beijing house prices is 0.0013 , and is statistically significant at the $5 \%$ level in the long run model. This result implies that a unit change (in Chinese RMB) in the cost of supply will affect Beijing house prices by $0.0013 \%$. On average, the Beijing house price is $8117.5 \mathrm{RMB}$ per square meter; when supply cost increases by 1 RMB per square meter, Beijing house prices will increase by 0.11 RMB per square meter. Our findings support the results published by Lv (2011) and Guo and Duan (2008). Lv (2011) analyzed house price dynamics using income and cost of supply. Guo and Duan (2008) modelled house price using cost of supply and the supply-demand relationship. Both studies reported a positive relationship between supply cost and house prices.

Table 3 shows a positive GDP growth coefficient (14.2145) for the short run model, which is significant at the $1 \%$ level. This implies that a $1 \%$ increase in the speed of GDP growth rate will increase the Beijing house price index by $14.2 \%$. The growth of income will increase housing affordability, which should positively impact the demand for houses. This is illustrated by Yang and Shen (2008), who investigated the Beijing housing market from 1990 to 2005. The authors reported that the income variable is one of the most important determinants of housing affordability in Beijing market. The authors also found that the impact of income on housing affordability is very large, especially for the first-time house buyers. Stone (2006) examined the fundamentals of housing affordability in the U.S. market, confirming that the income variable has a significant impact on house prices. The authors 
reported that gross family income determines how large a property loan the buyer can afford to repay, and that this significantly impacts housing affordability.

Table 3: Estimated Results of the Short Run Model (Equation 3 with quarterly data)

Dependent Variable: HPI

R-squared

Adjusted R-squared

S.E. of regression

Sum squared residual

Log likelihood

F-statistic

Probability(F-statistic)

Durbin-Watson stat
0.802037

0.749247

\subsection{6}

82.62517

$-42.56459$

15.19296

0.000037

1.961852

\begin{tabular}{lllll}
\hline & Coefficient & Std. Error & t-Statistic & Prob. \\
\hline C & 69.89013 & 8.890478 & 7.861234 & 0.0000 \\
LOG(GDPGROWTH) & 14.21448 & 3.020554 & $4.705919^{*}$ & 0.0003 \\
DLOG(CPI,0,4) & 45.84141 & 18.14815 & $2.525955^{*}$ & 0.0233 \\
IR & 1.465816 & 1.046576 & 1.400583 & 0.1817 \\
SUPPLYCOST & $5.78 \mathrm{E}-05$ & 0.000146 & 0.395731 & 0.6979 \\
\hline
\end{tabular}

Note: $*$ and $* *$ indicate significance at $5 \%$ and $1 \%$, respectively

Similar to the long run model, the inflation variable (45.8414) of the short run model is statistically significant. CPI also measures price factors that impact house prices such as price of raw materials and labor. This approach was utilised by Qiu (2011) in examining the relationship between house prices dynamics and CPI in China using an autoregressive distributed lag model, with data covering the period from 2004 to 2010. The author reported a significant positive link between CPI and house prices.

The interest rate coefficient is positive but insignificant. Changes in interest rate hurt the confidence of the real estate market, which is reflected in the demand for houses in the short run (Hu and Guan, 2011). This makes the interest rate statistically insignificant in the housing transaction.

The supply cost coefficient is also insignificant. Generally, building in a residential area includes several procedures such as land purchase, house design, build and sale. This implies the developers require a longer time period to complete the development of a housing tract (from land purchase to the sale of houses). For example, in China, building a housing development for commercial purposes (e.g., subdivisions of houses or multiple apartment buildings) normally takes 10 to 14 months. Therefore, changes in supply costs such as labor and raw material prices will not impact the construction costs of the house currently sold in the short run, especially pre-sale houses, since the developers will not know the actual 
construction costs. They only know the forecasted construction costs until they sell the house. This forecasted construction costs is predicted using previous construction costs data times the CPI.

\section{Conclusion}

Because of the lagged effect of supply cost and interest rate (current changes in fundamental variables did not capture the real costs of houses currently being sold), developers tend to use CPI to estimate the total costs of housing supply in the short run (based on quarterly data). However, in the long run (based on yearly data), developers already know their actual total costs of the housing supply; therefore, they tend to focus on the interest rate (borrowing costs) and supply cost (construction and operating costs) to make their decision about house supply and house prices. In general, developers make their decisions based on profit, which is defined as house prices minus total costs of their housing supply; therefore, for a given markup, the house supply is dependent on the total costs. As a result, the costs of capital (which depends on interest rate) and construction and operating costs (which depend on supply cost) significantly impact house price in the long run. However, in the short run, due to incomplete information about total house supply costs (such as what happens when most of the houses in a development are sold before they are completely built), housing developers can only use CPI as a proxy of the total costs of the housing supply to estimate their total costs. Therefore, CPI is more effective in explaining house price in the short run.

Hott and Monnin (2008) suggest that to test the existence of a housing bubble one should address the gap between real house price and its fundamental prices. Therefore, in order to provide descriptive evidence of the existence of housing bubbles in the Beijing housing market, we compared the movement between the house price index and the equilibrium house price index, incorporating the economic fundamental variables from our statistical model. Figures 1 and 2 show the movements of the real house price index and the equilibrium house price index from the long run (equation 2) and short run (equation 3) models, respectively.

In the short run model (Figure 2), the dotted line represents the equilibrium house price index in the Beijing housing market, building in the economic fundamental variables of income, inflation, interest rate and construction cost of house supply. The study results show two similar trends. The only significant differences appear in the last three quarters of 2006, in the second half-year of 2007 and 2010. Theoretically, a house price bubble exists when the real house price index is greater than the equilibrium house price index for a relatively extended period (e.g., three consecutive quarters). Therefore, the result of the short run model shows a housing bubble is very likely to have existed in the Beijing housing market from early in 2006 to 2007.

This conclusion from Figure 2 can be supported by the results of the long run model analysis. The large gap between house price and long-run fundamental price suggests the possibility of a house price bubble in the real estate market. In Figure 1, the house price index in 2005, 2006 and 2007 are greater than the equilibrium house price index, which suggests the 


\section{Macrothink}

existence of a bubble in the Beijing housing market. This interpretation of results is consistent with those of Hou (2009). Hou analyzed the relationship among house price, income and house rent. His analysis showed that the price to income ratio (P-I ratio) in the Beijing housing market increased from 7.6 to 17.1 during the 2004 to 2007 period; in the same period, the price-to-rent ratio (P-R ratio) in the Beijing housing market increased from 15 in 2004 to 32 in 2007. The author explained that the P-I ratio that market is more than $50 \%$ higher than the average P-I ratio for the developed regions in the eastern provinces of China. In general, the P-R ratio moves between 9 and 18. A ratio above 18 implies a potential price bubble in the housing market. The P-R ratio of Beijing rose over 18 and has remained so since 2005. Therefore, the author concluded the existence of a house price bubble in the Beijing housing market. Similarly, Wu, Gyourko and Deng (2012) reported historically high $\mathrm{P}-\mathrm{I}$ and P-R ratios in Beijing. This was especially so for the P-R ratio, which has experienced a near 70\% increase since 2007. Both Chovanec (2009) and Xu (2009) reported an extremely high P-I ratio in the Chinese housing market in their studies. As a result of our analysis, we can conclude the existence of a house price bubble affecting the Beijing housing market. Assuming that housing markets in very large cities will perform in relatively similar ways, it is quite possible that the results of our analysis will also apply to other large-scale metropolitan cities in China such as Shanghai, Guangzhou and Shenzhen.

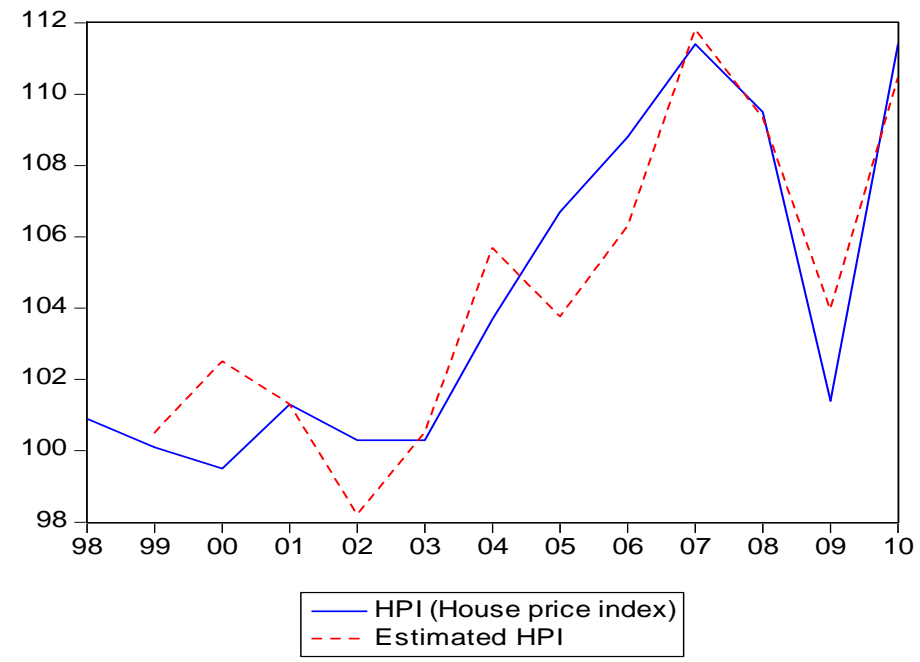

Figure 1: Long Run House Price Index (HPI) and Equilibrium HPI in Beijing 


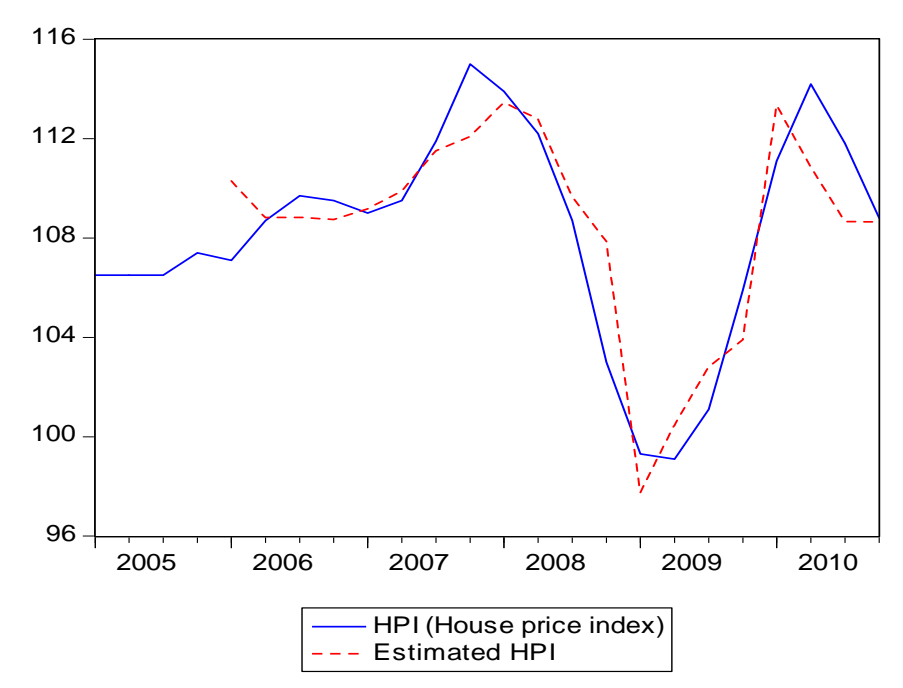

Figure 2: Short Run House Price Index (HPI) and Equilibrium HPI in Beijing

\section{References}

Abraham, J.M., \& Hendershott P.H. (1996). Bubbles in Metropolitan Housing Markets. Journal of Housing Research, 7(2), 191-207.

Abraham, J. M., \& Hendershott, P. H. (1993). Patterns and Determinants of Metropolitan House Prices 1977-1991. In Real Estate and the Credit Crunch, ed. Lynne E. Browne and Eric S. Rosengren, Boston, Federal Reserve Bank of Boston, 18-42.

Ayuso, J., Blanco, R., \& Restoy, F. (2006). House Prices and Real Interest Rate in Spain. Banco de Espana Research Paper No. OP-0608.

Black, A., Fraser, P., \& Hoesli, M. (2006). House Prices, Fundamentals and Bubbles. Journal of Business Finance and Accounting, 33(9), 1535-1555. http://dx.doi.org/10.1111/ j.1468-5957.2006.00638.x

Bloomberg News. (2007). Chinese Bank Has \$9 Billion in Subprime-Backed Securities. The New York Times, August 27 Retrieved from http://www.nytimes.com/2007/08/24/ business/worldbusiness/24yuan.html

Bodman, P., \& Crosby, M. (2004). Can Macroeconomic Factors Explain High House Prices in Australia? Australian Property Journal, 38(3), 174-179.

Bourassa, S., \& Hendershott, P. (1995). Australian Capital City Real House Prices 1979-1993. Australian Economic Review, 111, 16-26. http://dx.doi.org/10.1111/j.1467-8462.1995. tb00990.x

Caballero, R. J., \& Krishnamurty, A. (2005). Bubble and Capital Flow Volatility: Causes and Risk Management. Journal of Monetary Economics, 53, 1-22. 
Calhoun, C. A. (2003). Property Valuation Models and House Price Indexes for the Provinces of Thailand: 1992-2000. Housing Finance International, 17, 31-41.

Capozza, D. R., Hendershott, P. H., \& Mack, C. J (2004). An Anatomy of Price Dynamics in Illiquid Markets: Analysis and Evidence from Local Housing Markets. Real Estate Economics, 32(1), 1-32. http://dx.doi.org/10.1111/j.1080-8620.2004.00082.x

Case, K., Quigley, J.M., \& Shiller, R.J. (2005). Comparing Wealth Effects: The Stock Market versus the Housing. Advances in Macroeconomics, 5(1), 1-35. http://dx.doi.org/10.2202/ 1534-6013.1235

Case, K., \& Shiller, R. (2003). Is there a Bubble in the Housing Market? Brookings Papers on Economic Activity, 2, 299-362. http://dx.doi.org/10.1353/eca.2004.0004

Case, K. E., \& Shiller, R. J. (1989). The Efficiency of the Market for Single-Family Homes. American Economic Review, 79, 137-152.

Chan, H. L., Lee, S. K., \& Woo, K. Y. (2001). Detecting Rational Bubbles in the Residential Housing Markets of Hong Kong. Economic Modeling, 18(1), 61-73. http://dx.doi.org/ 10.1016/S0264-9993(00)00030-4

Chovanec, P. (2009). China’s Real Estate Riddle. Far East Economic Review, June 2009.

Coleman, M., LaCour-Little, M., \& Vandell, K. D. (2008). Subprime Lending and the Housing Bubble: Tail Wags Dog? Journal of Housing Economics, 17, 272-290. http://dx.doi.org/10.1016/j.jhe.2008.09.001

Clark, A., Frijters, P., \& Shields, M. A. (2008). Relative Income, Happiness and Utility: An Explanation for the Easterlin Paradox and Other Puzzles. Journal of Economic Literature, 46, 95-144. http://dx.doi.org/10.1257/jel.46.1.95

Crouhy, M. G., R.A.Jarrow., \& S.M.Turnbull (2008). The Subprime Crisis of 2007. Journal of Derivatives, 16(1), 81-110. http://dx.doi.org/10.3905/jod.2008.710899

Dreger, C., \& Zhang, Y. (2010). Is there a Bubble in Chinese Housing Market? DIW Berlin Discussion Paper No. 1081.

Durlauf, S. N., \& Hall, R. E. (1989). Bounds on the Variables of Specification Errors in Models with Expectations. NBER Working paper no. 2936

Fraser, P., Hoesli, M., \& McAlevey, L. (2008). House Prices and Bubbles in New Zealand. Journal of Real Estate Finance and Economics, 37, 71-91. http://dx.doi.org/10.1007/ s11146-007-9060-8

Gallin, J. (2006). The Long-Run Relationship between House Price and Income: Evidence from Local Housing Markets. Real Estate Economics, 34(3), 417-438. http://dx.doi.org/ 10.1111/j.1540-6229.2006.00172.x

Gallin, J. (2003). The Long-Run Relationship between House Prices and Rentals. Washington: Federal Reserve. 
Gao, B., \& Wang, X. Z. (2009). 中国房地产市场货币政策传导机制的有效性分析: 2000-2007. (Analysis of the Effectiveness of the Monetary Policy Transmission Mechanism in China's Real Estate Market: 2000-2007). Finance and Trade Economics, $3,129-135$

Garber, P. (2000). Famous First Bubbles: The Fundamentals of Early Manias. Cambridge: MIT Press.

Garino, G., \& Sarno, L. (2004). Speculative Bubbles in U.K. House Prices: Some New Evidence. Southern Economic Journal, 70(4), 777-795. http://dx.doi.org/10.2307/ 4135272

Gauger, J., \& Snyder, T. C. (2003). Residential Fixed Investment and the Macro Economy: Has Deregulation altered key Relationships? Journal of Real Estate Finance and Economics, 27, 335-354. http://dx.doi.org/10.1023/A:1025842108205

Global Property Guide (2007). Country Review, Malaysia. Retrieved from http://www.globalpropertyguide.com

Goodman, A. C., \& Thibodeau, T. G. (2008). Where are the Speculative Bubbles in US Housing Market? Journal of Housing Economics, 17, 117-137. http://dx.doi.org/ 10.1016/j.jhe.2007.12.001

Green, R. (1997). Follow the Leader: How Changes in Residential and Non-Residential Investment Predict Changes in GDP. Real Estate Economics, 25, 253-270. http://dx.doi.org/10.1111/1540-6229.00714

Guo, Y. Q., \& Duan, D. D. (2008). 基于房地产市场供求关系和产品成本的房价决定模 型,(A House Price Determined Model Based on Demand-Supply Relationship and Supply Costs). Journal of Lanzhou Studies, 52, 31-33.

Hatzi, E., \& Otto, G. (2008). Price, Rents and Rational Speculative Bubbles in the Sydney Housing Market. The Economic Record, 81, 96-103.

Hayford, M. D., \& Malliaris, A. G. (2010). Asset Prices and Financial Crisis of 2007-09: An Overview of Theories and Policies. Forum for Social Economics, 39(3), 279-286. http://dx.doi.org/10.1007/s12143-010-9062-9

Hott, C., \& Monnin, P. (2008). Fundamental Real Estate Price: An Empirical Estimation with International Data. The Journal of Real Estate Finance and Economics, 36(4), 427-450. http://dx.doi.org/10.1007/s11146-007-9097-8

Helbling, T., \& Terrones, M. (2003). When Bubbles Burst-Chapter II. World Economy Outlook. International Monetary Fund, 61-94.

Hou, Y. (2009). House Price Bubbles in Beijing and Shanghai? A Multi-Indicator Analysis. International Journal of Housing Markets and Analysis, 3(1), 17-37. http://dx.doi.org/ $10.1108 / 17538271011027050$

Hu, J. Y., \& Guan, Y. Z. (2011). 利率变动及居民收入支出对消费者购房信心的影响分析, 
(Analysis of the impact of Interest Rate Changes, Income and CPI on the Confidence of House Buyers). Business Times, 19, 14-15.

Hu, J., Su, L., Jin, S., \& Jiang, W. (2006). The Rise in House Prices in China: Bubbles or Fundamentals? Economic Bulletin, 3(7), 1-8.

Huang, H., \& Wang, B. (2007). 银行利率变动对房地产市场的影响 (The Impact of Interest Rate Changes on Housing Market). Price: Theory and Practice, 2007, 51-52.

Jannsen, N. (2009). National and International Business Cycle Effects of Housing Crisis. Kiel Working Paper No. 151.

Ji, M., \& Wang, Y. (2011). The Real Estate Market and the Inflationary Transmission Mechanism. China Money, 8, 4-8.

Kallberg, J. G., Liu, C. H., \& Pasquariello, P. (2002). Regime Shifts in Asian Equity and Real Estate Markets. Real Estate Economics, 30(2), 263-292. http://dx.doi.org/10.1111/ 1540-6229.00040

Kalra, S., Mihaljek. D., \& Duenwald, C. (2000). Property Prices and Speculative Bubbles: Evidence from Hong Kong SAR. IMF Working Paper No. 00/2, January.

Kang, H. B., \& Gardner, M. (1989). Selling Price and Marketing Time in the Residential Estate Market. Journal of Real Estate Research, 4(1), 21-35.

Kau, J. B., \& Keenan, D. (1980). The Theory of Housing and Interest Rate. Journal of Financial and Quantitative Analysis, 15(4), 833-847. http://dx.doi.org/10.2307/2330560

Keynes, J.M. (1930). A Treatise on Money. New York: Macmillan Publishing Company.

Kim, K. W., \& Kim, H. N. (2009). Global Financial Crisis Overview. SERI Quarterly, April, 13-21.

Kim, K. H. (2004). Housing and the Korean Economy. Journal of Housing Economics, 13(4), 321-341. http://dx.doi.org/10.1016/j.jhe.2004.09.001

Kim, K. H., \& Suh, S. H. (1993). Speculation and Price Bubbles in the Korean and Japanese Real Estate Markets. Journal of Real Estate Finance and Economics, 6, 73-87. http://dx. doi.org/10.1007/BF01098429

Krinsman, A.N. (2007). Subprime Mortgage Meltdown: How Did it Happen and How Will It End? Journal of Structured Finance, 13(2), 13-19. http://dx.doi.org/10.3905/ jsf.2007.690261

Leamer, E.E. (2007). Housing is the Business Cycle. National Bureau of Economic Research Working Paper No. 13428.

Leung, C. K. U., \& Wang, W. (2007). An Examination of the Chinese Housing Market through the Lens of the DiPasquale-Wheaton Model: A Graphical Attempt. International Real Estate Review, 10(2), 131-165. 
Levin, E. J., \& Pryce, G. (2007). A Statistical Explanation for Extreme Bids in the House Market. Urban Studies, 44(11), 2339-2355. http://dx.doi.org/10.1080/00420980701540 903

Levin, E. J., \& Wright, R. E. (1997). The Impact of Speculation on House Prices in the United Kingdom. Economic Modeling, 14(4), 567-585. http://dx.doi.org/10.1016/S02649993(97)00008-4

Linneman, P. D., \& Megbolugbe, I. F. (1992). Housing Affordability: Myth or Reality? Urban Studies, 29(3-4), 369-392. http://dx.doi.org/10.1080/00420989220080491

Lv, P. (2011), 我国住房生产成本对房价的影响分析,(The Impact of the Cost of House Supply on House Prices). Price: Theory and Practice, 2010, 62-63.

Malpezzi, S., \& Wachter, S. (2005). The Role of Speculation in Real Estate Cycles. Journal of Real Estate Literatures, 13(2), 143-166.

Malpezzi, S., \& Chun, G. H., \& Richard, K. G. (1998). New Place-to-Place Housing Price Indexes for U.S. Metropolitan Areas, and their Determinants. Real Estate Economics, 26(2), 235-274. http://dx.doi.org/10.1111/1540-6229.00745

McCarthy, J., \& Peach, R. W. (2005). Is there a "Bubble" in the Housing Market now? Network Financial Instrument, 2005-PB-01.

McCarthy, J., \& Peach, R. W. (2004), Are House Prices the Next "Bubble"? Economy Policy Review, Federal Reserve Bank of New York, 10(3), 1-17.

McQuinn, K., \& O'Reilly, G. (2006). Assessing the Role of Income and Interest Rates in Determining House Prices. Economic Modeling, 25, 377-390. http://dx.doi.org/10.1016/ j.econmod.2007.06.010

Meen, G. P. (1990). The Removal of Mortgage Market Constraints and the Implications for Econometric Modeling of UK House Prices. Oxford Bulletin of Economic and Statistic, 52(1), 1-23. http://dx.doi.org/10.1111/j.1468-0084.1990.mp52001001.x

Peng, W.S. (2002). What Drives Property Price in Hong Kong? HKMA Quarterly Bulletin, August.

Pillay, S., \& Rangel, Gary. (2005). Evidence and Determinants of Real Estate Bubbles: The Case of Singapore. The 16th Asian Finance Association Conference Proceedings, Paper No. 37.

Qi, L., \& Li, G (2004). Efficiency of Thin and Thick Markets: Working Paper No. 11813, National Bureau of Economic Research.

Qiu, Y. (2011), 房价波动与 CPI 关系的计量分析,(Analysing the Relationship between House Price Dynamics and CPI) Ministry of Education, Humanities and Social Science Project),(10YJA790271), 26(1), 43-46.

Quigley, J.M. (2001). Real Estate and the Asian Crisis. Journal of Housing Economics, 10(2) 
129-161. http://dx.doi.org/10.1006/jhec.2001.0284

Quigley, J. M. (1999). Real Estate Prices and Economic Cycles. International Real Estate Review, 2(1), 1-20.

Shen, Y., Hui, E. C., \& Liu, H. (2005). Housing Price bubble in Beijing and Shanghai. Management Decision, 43(4), 611-627. http://dx.doi.org/10.1108/00251740510593594

Shiller, R. J. (2007). Understanding Recent Trends in House Prices and Home Ownership. Paper presented at the Federal Reserve Bank of Kansas City's Jackson Hole Symposium, Kansas City, August 31- September 1, 2007.

Sing, T. B., I.C., T., \& Chen, M. C. (2006). Price Dynamics in Public and Private Housing Markets in Singapore. Journal of Housing Economics, 15, 305-320. http://dx.doi.org/ 10.1016/j.jhe.2006.09.006

Stone, M. E. (2006). What is Housing Affordability? The Case for the Residual Income Approach. Housing Policy Debate, 17(1), 151-184. http://dx.doi.org/10.1080/10511482. 2006.9521564

Taylor, J.B (2007). Housing and Monetary Policy. Proceedings of the Jackson Hole Symposium. Federal Reserve Bank of Kansas City, August.

Unterman, A. (2009). Innovative Destruction-Structured Finance and Credit Market Reform in the Bubble Era. Hasting Business Literature Review, 5, 53-65.

Wang, X. Z., \& Zhao, F. J. (2010), 房地产市场货币政策效应一基于我国 35 个大中型城市 的实证分析 (The Impact of the Monetary Policy on Housing Market: A Case Study Based on 35 Cities in China) Economic Structural Reform, 3, 157-161.

Wong, G.B. (2008). The Anatomy of a Housing Bubble," The Selected Works of Grace Wong Bucchianeri. Retrieved from http://works.bepress.com/gwb/5

Wong, K-Y. (2001). Housing Market Bubbles and the Currency Crisis: The Case of Thailand. Japanese Economic Review, 52(4), 382-404. http://dx.doi.org/10.1111/1468-5876. 00202

Wu, J., Gyouko, J., \& Deng, Y. H. (2012). Evaluation Conditions in Major Chinese Housing Markets. Regional Science and Urban Economics, 42(3), 531-543. http://dx.doi.org/ 10.1016/j.regsciurbeco.2011.03.003

Xiao, Q., \& Tan, G. (2007). Signal Extraction with Kalman Filter: A Study of the Hong Kong Property Price Bubbles. Urban Studies, 44(4), 865-888. http://dx.doi.org/10.1080/ 00420980601185650

Xu, S. L. (2009). An Affordable Home for Every Family, Chongqing Official Promises. Global Times, September. Retrieved from http://www.china.org.cn/

Yang, Z., \& Shen, Y. (2008). The Affordability of Owner Occupied Housing in Beijing. Journal of Housing and Built Environment, 23, 317-335. http://dx.doi.org/10.1007/ 
s10901-008-9120-2

Yun, T., Wang, J., Hui, C. M. E., \& Seabrook, W. (2003). The Impact of Interest Rates upon Housing Prices: An Empirical Study of Hong Kong's Market. Journal of Property Management, 21(2), 153 - 170. http://dx.doi.org/10.1108/02637470310478891

Zhou, W.X., \& Sornette, D. (2008). Analysis of the Real Estate Market in Las Vegas: Bubble, Seasonal Patterns, and Prediction of the CSW Indexes, Physica A, 387, 243-260. http://dx.doi.org/10.1016/j.physa.2007.08.059

Zhou, W.X., \& Sornette, D. (2003). 2000-2003 Real Estate Bubble in the UK but not in the US. Physica A, 329, 249-263. http://dx.doi.org/10.1016/S0378-4371(03)00600-9

\section{Copyright Disclaimer}

Copyright reserved by the author(s).

This article is an open-access article distributed under the terms and conditions of the Creative Commons Attribution license (http://creativecommons.org/licenses/by/3.0/). 